\title{
Satellite Data for Agricultural Drought Analysis in Chile
}

\author{
Francisco Zambrano Bigiarini ${ }^{1 *}$ \\ Department of Water Resources, Universidad de Concepción, Chile
}

Submission: February 03, 2017; Published: February 27, 2017

"Corresponding author: Francisco Zambrano Bigiarini, Department of Water Resources, Universidad de Concepción, Av Vicente Méndez 595, Casilla 527, Chillán, Chile, Email: frzambra@gmail.com

\section{Abstract}

Agricultural drought in Chile has been studied using the Normalized Difference Vegetation Index (NDVI) and the Vegetation Condition Index (VCI), derived from NDVI. In addition, satellite-derived Standardized Precipitation Index (SPI) has been used as an indirect measure. However, there are other remote sensing data, such as Land Surface Temperature (LST), Phenology Dynamics, Evapotranspiration (ET), and Soil Moisture (SM), which provide useful information to carry out more detailed analyses. Moreover, a main challenge to improve scientific findings is to collect data about crops such as type, seasonality, and yield, in order to generate a national database, which along with satellite indices, will be essential to develop spatial crop models; thereby, broadening knowledge regarding the impact of agricultural drought in Chile

\section{Introduction}

IPCC [1] forecasts precipitation decrease in the centralsouthern region of Chile that would increase drought frequencies and intensities. Future scenarios predict that by 2050 , wheat and corn yields will decrease by $5 \%$ to $20 \%$ IPCC [2]; Meza \& Silva [3]; however, impacts on agricultural production could be greater if taking onboard effects on cropping frequency and area [4]. Nowadays, there has been an increment in the number of remote sensing products for climate [5] and agriculture applications [6] that provide great opportunities to carry out drought studies [7], especially for developing countries like Chile.

\section{Vegetation and precipitation indices}

Since the drought of 2008, remote sensing data has been used in Chile as useful information to monitor agricultural drought. Indices as the Normalized Difference Vegetation Index (NDVI) [8] and the Vegetation Condition Index (VCI) [9] have been adopted by the Chilean Agroclimatic Observatory (OAC for its acronym in Spanish) (www.climatedatalibrary.cl), along with the Standardized Precipitation Index (SPI) at short-time scales, based on rain gauges and satellite, used as indirect measure of agricultural drought. Zambrano et al. [10] proved that VCI is a useful tool for monitoring agricultural drought in the centralsouthern region of Chile, comparing this index with the well known Standardized Precipitation Index (SPI) [11] obtained from weather stations, and with governmental declarations regarding the emergency drought between 2000 and 2015 .
Zambrano et al. [10] used remote sensing products from the Moderate Resolution Imaging Spectroradiometer (MODIS), specifically, MOD13Q1 [12]-product regarding vegetation indices that provides data every 16 days at 250-meter spatial resolutionand MCD12Q1 [13]-product that provides data regarding land cover yearly at 500-meter spatial resolution-used to generate a cropland mask and then isolate the agricultural area.

Satellite-derived SPIs between 1981 and 2015, at time-scale of 1,3 , and 6 months, were evaluated for its application on Chile during agricultural drought [14], using 278 weather station to assess the agreement between satellite and in-situ SPIs. Climate Hazards Group Infra Red Precipitation with Station (CHIRPS) [15] product, at 5-kilometer spatial resolution, showed good results in the central region of Chile, unlike in the southern and northern regions. Therefore, this product is a viable alternative for data sources spatially distributed rainfall in Chile.

\section{Recent satellite data and drought indices}

Besides vegetation and precipitation satellite data for application in agricultural drought, there are new remote sensing datasets, such as Evapotranspiration (ET) [16,17], Soil Moisture (SM) [18], Land Surface Temperature (LST), and phenology dynamics [11], which could be evaluated for its application in Chile. As indicated by Mishra et al. [19], the agricultural drought will differ between crops because of two major factors: demand and supply, which could be estimated using satellite data. 
Water demand depends on climate and specific crop characteristics. Perhaps, the most relevant measure of crop water demand is ET, which has been used in the formulation of drought indices like the Drought Severity Index (DSI) [20] and the Standardized Precipitation Evapotranspiration Index (SPEI) [21]. The effect of temperature in agriculture could be analyzed through LST, used to derive the Temperature Condition Index (TCI) [9], which determines stress on vegetation caused by temperatures. Another main characteristic of crop water demand is the growing season, period during the agricultural drought indices most be considered. To achieve this analysis of NDVI, time-series has been generally used to estimate the seasonality [22,23] also product MCD12Q2 for land cover dynamics [24] from MODIS provide seasonality dates globally as a useful dataset.

Soil moisture (SM) is a water supply measure which will be used for plant development and to know the impact on yield well; this should be considered in the root zone depth Mishra et al. [19]. Two of the latest satellite soil moisture products are:

A. Climate Change Initiative (CCI) [18], part of the ESA Programme on Global Monitoring of Essential Climate Variables (ECV), which has $\approx 25$-kilometer spatial resolution and daily frequencies and

B. Soil Moisture Active Passive (SMAP) [25], which has 9-kilometer spatial resolution and frequencies of 7 days and the advantage that considers the soil moisture for the root zone depth. From soil moisture data, there are several drought indices, such as the Drought Severity Index (DSI) [26] and the Soil Moisture Deficit Index (SMDI) [27].

\section{Conclusion}

In order to study agricultural drought in Chile, satellite indices that measure vegetation response, such as NDVI and VCI [10], have been used. In addition to satellite-derived precipitation indices like SPI [14]. These indices have allowed generating a baseline in the understanding of agricultural drought process in Chile.

Future works should consider the use of new satellite data, such as LST, SM, ET, and phenology, in order to improve agricultural drought analyses. These data, along with new analysis techniques, will be useful to develop a model that helps to anticipate agricultural drought $[28,29]$.

In addition, there is a gap in the studies presented in Chile regarding to the use of crop data to validate satellite data, mainly because it implies a lot of work to collect. A considerable challenge is to generate a national database about crops which will be crucial to advance in the knowledge of agricultural drought impact at the level of crop type through Chile.

\section{Reference}

1. IPCC (2013) Climate Change 2013: The Physical Science Basis. Contribution of Working Group I to the Fifth Assessment Report of the
Intergovernmental Panel on Climate Change. Cambridge University Press, Cambridge, New York, USA.

2. IPCC (2014) Climate Change 2014: Impacts, Adaptation, and Vulnerability. Part A: Global and Sectoral Aspects. Contribution of Working Group II to the Fifth Assessment Report of the Intergovernmental Panel of Climate Change. USA, p. 1-207.

3. Meza FJ, Silva D (2009) Dynamic adaptation of maize and wheat production to climate change. Climatic Change 94(1):143-156.

4. Cohn AS, VanWey LK, Spera SA, Mustard JF (2016) Cropping frequency and area response to climate variability can exceed yield response. Nature Climate Change 6: 601-604.

5. Yang J, Gong P, Fu R, Zhang M, Chen J, et al. (2013) The role of satellite remote sensing in climate change studies. Nature Climate Change 3 : 875-883.

6. Brown ME (2015) Satellite remote sensing in agriculture and food security assessment. Procedia Environmental Sciences 29: 307.

7. Agha Kouchak A, Farahmand A, Melton FS, Teixeira J, Anderson MC et al. (2015) Remote sensing of drought: Progress, challengesand opportunities. Reviews of Geophysics 53(2): 452-480.

8. Rouse JW, Haas RH, Schell JA, Deering DW (1974) Monitoring Vegetation Systems in the Great Plains with Erts. NASA Special Publication 351: 309-317.

9. Kogan F, Salazar L, Roytman L (2012) Forecasting crop production using satellite-based vegetation health indices in kansas, USA. International Journal of Remote Sensing 33(9): 2798-2814.

10. Zambrano F, Lillo-Saavedra M, Verbist K, Lagos O (2016) Sixteen years of agricultural drought assessment of the BioBío Region in Chile using a $250 \mathrm{~m}$ resolution Vegetation Condition Index (VCI). Remote Sens 8(6): 530.

11. McKee TB, Doesken NJ, Kleist J (1993) The relationship of drought frecuency and duration to time scales. In In Proceedings of the International $8^{\text {th }}$ Conference on Applied Climatology. American Meteorological Society, Anaheim, CA, USA, p. 179-184.

12. Didan K (2015) Mod13q1 modis/terra vegetation indices 16-day l3 global $250 \mathrm{~m}$ sin grid v006.

13. Friedl MA, Sulla-Menashe D, Tan B, Schneider A, Ramankutty N, et al (2010) MODIS collection 5 global land cover: Algorithm refinements and characterization of new datasets. Remote Sens Environ 114(1): 168-182.

14. Zambrano F, Wardlow B, Tadesse T, Lillo-Saavedra M, Lagos O (2017) Evaluating satellite-derived long-term historical precipitation dataset for drought monitoring in chile. Atmospheric Research 186: 26-42.

15. Funk C, Peterson P, Landsfeld M, Pedreros D, Verdin J, et al. (2014) A quasi global precipitation time series for drought monitoring. Technical report, US Geological Survey Data Series, USA, p. 832.

16. Mu Q, Heinsch FA, Zhao M, Running SW (2007) Development of a global evapotranspiration algorithm based on MODIS and global meteorology data. Remote Sens Environ 111(4): 519- 536.

17. Mu Q Zhao M, Running SW (2011) Improvements to a MODIS global terrestrial evapotranspiration algorithm. Remote Sensing of Environment 115(8): 1781-1800.

18. Dorigo W, Gruber A, Jeu RD, Wagne W, Stacke T, et al. (2015) Evaluation of the $\{\mathrm{ESA}\}\{\mathrm{CCI}\}$ soil moisture product using ground-based observations. Remote Sensing of Environment 162: 380- 395.

19. Mishra AK, Ines AV, Das NN, Khedun CP, Singh VP, et al. (2015) Anatomy of a local-scale drought: Application of assimilated remote sensing products, crop model, and statistical methods to an agricultural drought study. J Hydrol 526: 15- 29. 
20. Mu Q Zhao M, Kimball JS, McDowell NG, Running SW (2013) A remotely sensed global terrestrial drought severity index. Bull Amer Meteor Soc 94(1): 83-98.

21. Vicente-Serrano SM, Beguería S, López-Moreno JI (2010) A multiscalar drought index sensitive to global warming: The standardized precipitation evapotranspiration index. J Clim 23(7): 1696-1718.

22. Atkinson PM, Jeganathan C, Dash J, Atzberger C (2012) Intercomparison of four models for smoothing satellite sensor time-series data to estimate vegetation phenology. Remote Sens Environ 123: 400- 417.

23. Vrieling A, de Beurs KM, Brown ME (2011) Variability of african farming systems from phenological analysis of ndvi time series. Clim Chang 109(3): 455-477.

24. Ganguly S, Friedl MA, Tan B, Zhang X, Vermab M (2010) Land surface phenology from MODIS: Characterization of the collection 5 global land cover dynamics product. Remote Sensing of Environment, 114(8): 1805-1816.

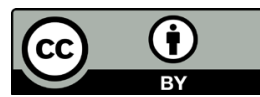

This work is licensed under Creative Commons Attribution 4.0 License

DOI:_10.19080/ARTOAJ.2017.04.555633
25. Colliander A, Jackson T, Bindlish R, Chan S, Das N, et al. (2017) Validation of $\{$ SMAP $\}$ surface soil moisture products with core validation sites. Remote Sensing of Environment 191: 215-231.

26. Cammalleri C, Micale F, Vogt J (2015) A novel soil-moisture-based drought severity index (DSI) combining water deficit magnitude and frequency. Hydrological Processes 30(2): 289-301.

27. Levy AN, MacCracken S, Mastrandrea PR, White LL, Porter JR. Cambridge University Press, Cambridge, New York, USA, p. 1132.

28. Kogan FN (1995) Application of vegetation index and brightness temperature for drought detection. Adv Space Res 15(11): 91-100.

29. Narasimhan B, Srinivasan R (2005) Development and evaluation of Soil Moisture Deficit Index (SMDI) and Evapotranspiration Deficit Index (ETDI) for agricultural drought monitoring. Agricultural and Forest Meteorology 133(1-4): 69-88.

\section{Your next submission with Juniper Publishers will reach you the below assets}

- Quality Editorial service

- Swift Peer Review

- Reprints availability

- E-prints Service

- Manuscript Podcast for convenient understanding

- Global attainment for your research

- Manuscript accessibility in different formats

( Pdf, E-pub, Full Text, Audio)

- Unceasing customer service

Track the below URL for one-step submission https://juniperpublishers.com/online-submission.php 